\title{
The influence of population density on outcrossing rates in Mimulus ringens
}

\author{
JEFFREY D. KARRON*, NINA N. THUMSER, ROSELLA TUCKER \& AMY J. \\ HESSENAUER \\ Department of Biological Sciences, P. O. Box 413, University of Wisconsin-Milwaukee, Milwaukee, WI 53201, U.S.A.
}

\begin{abstract}
The influence of population density on pollinator movements and outcrossing rates was studied in experimental arrays of Mimulus ringens (square-stemmed monkeyflower), a wetland perennial species with a mixed-mating system. Each population was composed of genets with unique multilocus combinations of homozygous genotypes, facilitating determination of outcrossing rates through paternity exclusion. Replicate arrays were cloned from the same set of genets to minimize differences in floral and vegetative morphology among density treatments. Two arrays were planted at each of three spacings typical of the range of densities found in natural $M$. ringens populations. Both the proportion of pollinator flights between plants and the frequency of outcrossing were significantly greater at high density. These results suggest that ecological and demographic factors, such as population density, can significantly influence levels of inbreeding in species with mixedmating systems.
\end{abstract}

Keywords: density, experimental arrays, geitonogamy, outcrossing rate, paternity analysis, pollinator movements.

\section{Introduction}

In several species of animal-pollinated flowering plants, outcrossing rates vary dramatically among populations (Harding \& Barnes, 1977; Valdeyron et al., 1977; Ellstrand et al., 1978; Schoen, 1982; Schemske \& Lande, 1985; Ritland \& Ganders, 1987a; Waller \& Knight, 1989; Barrett \& Husband, 1990; Dole, 1991; Godt \& Hamrick, 1991). This variation is often attributed to ecological factors, such as population density, that influence pollinator movements (Aide, 1986; Waller, 1986; Brown et al., 1989; Watkins \& Levin, 1990; Murawski \& Hamrick, 1991; Lloyd \& Schoen, 1992). Despite theoretical predictions that outcrossing rates will be positively correlated with population density (Bateman, 1956; Handel, 1983; Brown et al. 1989), the relationship between these variables remains poorly understood.

Most studies documenting intraspecific variation in plant mating systems have involved comparisons of natural populations. However, in nature, population density is often confounded with other demographic variables such as plant size, population shape and population size (Barrett \& Eckert, 1990; Kunin, 1993; Karron, 1995). In addition, differences among populations in genetically determined floral traits influencing

*Correspondence. the mating system (Campbell \& Abbott, 1976; Schoen, 1982; Marshall \& Abbott, 1984; Wyatt, 1984a,b; Holtsford \& Ellstrand, 1989, 1992; Barrett \& Husband, 1990; Clegg \& Epperson, 1988; Morgan \& Barrett, 1990) may further limit the utility of descriptive studies correlating population density with outcrossing rate.

The influence of density on plant mating systems is well suited to experimental study. Spacing between plants is readily manipulated in population arrays, and recent experiments have examined the effects of density on patterns of pollinator movement and seed set in self-incompatible species (Kunin, 1992, 1993). Artificial arrays have also been used to determine outcrossing rates of distinct floral morphs in polymorphic populations (Epperson \& Clegg, 1987; Barrett \& Eckert, 1990; Kohn \& Barrett, 1992; Motten \& Antonovics, 1992).

In this paper we examine the influence of population density on mating patterns in Mimulus ringens (squarestemmed monkeyflower). Natural populations of this species have a mean outcrossing rate of 0.34 (Karron, unpublished) and occur at a wide range of densities.

Our study tested two hypotheses: (1) the proportion of pollinator flights among plants will be greater at higher population densities; (2) the rate of outcrossing will be greater at higher population densities. These predictions follow from Bateman's (1956) observation 
that geitonogamous (within-plant) pollinations are more frequent at low population densities because foraging pollinators tend to fly short distances. Both hypotheses were tested by establishing experimental arrays composed of genets with unique multilocus combinations of homozygous genotypes. This approach greatly increased the precision of outcrossing rate estimates because we determined paternity for each sampled seed. To minimize differences in floral and vegetative morphology among density treatments, all six arrays were cloned from the same set of genets.

\section{Materials and methods}

\section{Study organism}

Mimulus ringens L. (Scrophulariaceae) is a diploid perennial herb that is widely distributed in central and eastern North America (Grant, 1924). The species is usually found in wetlands, and populations typically have fewer than 50 individuals. In northern Illinois and southern Wisconsin, $M$. ringens flowers in July and August. Plants produce hundreds of hermaphroditic flowers, each lasting for 1-2 days. The showy blue corollas measure $2.9-3.4 \mathrm{~cm}$ in length and $1.9-2.6 \mathrm{~cm}$ in width and are primarily visited by workers and queens in the genus Bombus (bumblebees). Like many of its congeners (Sutherland \& Vickery, 1988; Ritland \& Ritland, 1989; Dole, 1990, 1992; Robertson et al., 1994), $M$. ringens is self-compatible and will produce some selfed seed in the absence of pollinators. However, the stigma is exserted 0.5 to $2.5 \mathrm{~mm}$ above the top pair of anthers, a morphology that reduces autogamy in several members of the genus (Darwin, 1876; Kiang, 1972; Ritland \& Ritland, 1989; Carr \& Fenster, 1994).

Mimulus ringens also reproduces vegetatively through the production of stoloniferous rhizomes (Grant, 1924). After one season of growth under normal field conditions, 6-month-old plants typically produce 10-40 vegetative propagules (personal observation). If these rhizomes are divided, subjected to a cold treatment at $4^{\circ} \mathrm{C}$ to break dormancy, and planted the following spring, they will grow into mature flowering plants in 90-110 days.

\section{Breeding of genets with unique marker genotypes}

Paternity exclusion is facilitated if each individual in an experimental array is homozygous for unique combinations of alleles at several different loci (Brown et al., 1989). To ensure that these homozygous allozyme genotypes did not result from a history of inbreeding, the marker genotypes were produced through outcrossing of multilocus heterozygotes.
Fruits were bulk-harvested from a population in Kane County, Illinois and multilocus genotypes of 1500 seedlings were determined at the four polymorphic loci described below. Twenty-two offspring were heterozygous at all four loci and were crosspollinated in a diallel design. Two thousand seeds harvested from the 231 crosses were germinated and genotyped to identify 16 genets with unique multilocus combinations of homozygous genotypes. The genets were grown in the greenhouse until each had produced at least 10 stoloniferous rhizomes. The propagules were then divided and subjected to a 3-month cold treatment at $4^{\circ} \mathrm{C}$.

\section{Electrophoretic procedures}

Tissue from young leaves was ground in the extraction buffer of Ritland (1989). Shikimate dehydrogenase (Skd-1, EC 1.1.1.25) and aconitase (Aco-3, EC 4.2.1.3) were resolved on horizontal starch gels with a histidine-citrate pH 5.7 buffer (Stuber et al., 1977). The histidine-citrate gels were run for $7.5 \mathrm{~h}$ at $40 \mathrm{~mA}$. Glutamate oxaloacetate transaminase (Got-1, EC 2.6.1.1) and acid phosphatase (Acp-1, EC 3.1.3.2) were resolved on starch gels with a lithium-borate $\mathrm{pH}$ 8.1 buffer (Ridgeway et al., 1970). The lithium-borate gels were run for $5.5 \mathrm{~h}$ at $65 \mathrm{~mA}$. Staining protocols followed Wendel \& Weeden (1989).

\section{Planting of experimental arrays}

Six randomly-selected clones of each genet were placed in a cold frame for 2 weeks, allowing them to acclimatize to ambient air temperatures. Replicate sets of the 16 genets were planted in six experimental gardens at the UW-Milwaukee Field Station (Saukville, Wisconsin). Soil composition and drainage were uniform within and among the gardens (James Reinartz, personal communication). To minimize gene dispersal between arrays, the gardens were separated by at least $75 \mathrm{~m}$. The old field vegetation surrounding each garden had a high density of bumblebeepollinated flowers, further reducing the probability of gene dispersal between experimental populations. Long-distance gene flow from natural populations of $M$. ringens was unlikely since the nearest natural population was more than $15 \mathrm{~km}$ away.

Each garden was tilled prior to planting and mulched with hay to minimize weeds. The 16 genets were planted in square arrays (four parallel rows, each with four evenly-spaced plants per row). Positions of clones in each array were randomly assigned. Two gardens were selected at random and planted with 'high density' arrays (0.6 m spacing between plants), 
two gardens were planted with 'medium density' arrays (1.2 $\mathrm{m}$ spacing), and two gardens were planted with 'low density' arrays ( $2.4 \mathrm{~m}$ spacing). This 16 -fold range in density corresponds to the range typically observed in natural populations of $M$. ringens.

\section{Pollinator observations}

Movements of pollinators visiting $M$. ringens were recorded on 8 days during the peak period of flowering. Pollinator flights within each array were noted during sequential 20-minute sampling intervals that were assigned in random order to the six populations. Each pollinator flight segment was classified as either (1) a flight between flowers on a single plant or (2) a flight between flowers on different plants. To investigate whether the frequency of between-plant pollinator flights was consistent across density treatments, data from this split-plot design were tested with a $\chi^{2}$ analysis (Steel \& Torrie, 1980; SAS Institute, 1990).

\section{Inheritance of male sterility in three clonal lines}

In all six arrays, clones $\mathrm{M}, \mathrm{P}$ and $\mathrm{Q}$ had very low levels of pollen production. Male sterility has previously been documented in populations of Mimulus guttatus (Ritland \& Ganders, 1987b; Dole, 1991; Willis, 1993; Robertson et al., 1994) and may be inherited as either a gene of major effect (Willis, 1993) or as a quantitative trait (Robertson et al., 1994). It occurred in 3.9 per cent of the $M$. ringens offspring harvested from the Kane County population. All 22 parents in the earlier diallel crosses were pollen fertile, suggesting that male sterility is inherited as a recessive allele at a single locus. To test this prediction, we self-fertilized the three paternal parents of clones $\mathrm{M}, \mathrm{P}$ and $\mathrm{Q}$. The inbred progeny arrays were grown to flowering in the greenhouse and the male fertility phenotype of each plant was determined. To investigate further the genetic basis of male sterility, clones $\mathrm{M}, \mathrm{P}$ and $\mathrm{Q}$ were crossed with pollen from four unrelated donors. Ten outcrossed progeny from each of the clones were grown to flowering, and the male fertility phenotype of each plant was recorded.

\section{Determination of outcrossing rates}

Thirty-five fruits were harvested from each maternal plant in the six experimental arrays. To ensure that sampling spanned the entire period of fruit ripening, seven fruits were removed from each plant on September 7, 14 fruits were harvested on September 14, and 14 fruits were harvested on September 21. All seeds from a maternal parent were pooled together and a portion was sown in a single pot. Germination rates exceeded 90 per cent. Two-week-old seedlings were transplanted individually into $5 \mathrm{~cm}$ square cells in plastic flats.

Twenty 6-week-old seedlings were randomly selected from each of the 96 progeny arrays, and these 1920 seedlings were genotyped at the four variable loci. Since maternal plants were homozygous at each locus, all progeny resulting from selfing were also homozygous at these loci. By contrast, outcrossed progeny were heterozygous at one or more loci, and their paternity was assigned with a simple exclusion procedure (Ellstrand, 1984; Brown et al., 1989; Karron, 1995). To investigate whether the frequencies of selfing and outcrossing were consistent across density treatments, paternity data for seeds of the 78 pollen-fertile clones in this split-plot design were tested with a $\chi^{2}$ analysis (Steel \& Torrie, 1980; SAS Institute, 1990).

\section{Results}

Nearly all of the pollinators visiting the experimental populations were Bombus workers and queens. The arrays had similar numbers of open flowers and comparable rates of floral visitation by pollinators (Table 1).

The relative frequency of between-plant pollinator flights varied significantly across density treatments $\left(\chi_{2}^{2}=282.1, P<0.0001\right)$ and was greatest in the two high-density populations (Fig. 1a). The frequency of outcrossing also varied significantly among density treatments $\left(\chi_{2}^{2}=48.4, P<0.0001\right)$. The highest rates of outcrossing occurred in the two high-density populations (Fig. 1b).

Nearly pollen-sterile clones $\mathrm{P}$ and $\mathrm{Q}$ had outcrossing rates of 100 per cent in all six populations. Clone $M$ was also completely outcrossing in five populations, but had a selfing rate of 10 per cent in one of the lowdensity populations.

Two lines of evidence suggest that male sterility in this population is inherited as a recessive allele at a

Table 1 Number of open flowers on August 10 and mean number of pollinator floral visits per hour in the six experimental arrays of Mimulus ringens

\begin{tabular}{lcc}
\hline Population & $\begin{array}{c}\text { Open flowers } \\
\text { on Aug. 10 }\end{array}$ & $\begin{array}{c}\text { Pollinator floral } \\
\text { visits per hour }\end{array}$ \\
\hline Low density 1 & 1053 & 370.9 \\
Low density 2 & 650 & 325.1 \\
Medium density 1 & 940 & 428.3 \\
Medium density 2 & 973 & 551.6 \\
High density 1 & 832 & 321.4 \\
High density 2 & 904 & 415.9 \\
\hline
\end{tabular}



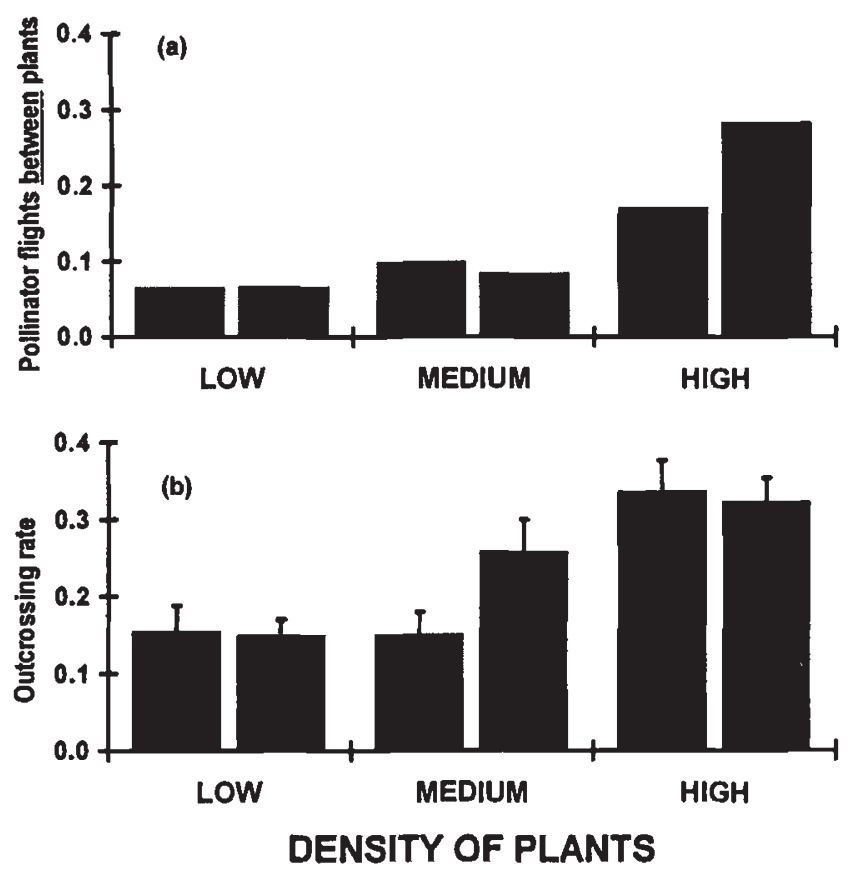

Fig. 1 (a) The proportion of pollinator flights between plants in six experimental populations of Mimulus ringens. (b) Mean outcrossing rates of pollen-fertile clones ( $+1 \mathrm{SE}$ ) in six experimental populations of $M$. ringens. See text for data analyses.

single locus. When three parents of $\mathrm{M}, \mathrm{P}$ and $\mathrm{Q}$ were self-fertilized, the male fertility phenotypes of the offspring did not differ significantly from the expected 3:1 ratio. (One parent had 11 fertile and five sterile offspring, $\chi_{1}^{2}=0.33$; the second parent had 17 fertile and five sterile offspring, $\chi_{1}^{2}=0.06$; and the third parent had eight fertile and four sterile offspring, $\chi_{1}^{2}=0.44$.) When presumed homozygotes $M, P$ and $Q$ were crossed with pollen from four unrelated donors, all 30 sampled offspring were pollen-fertile.

\section{Discussion}

The positive relationship between population density and outcrossing rate is likely to have resulted from differences in patterns of pollinator movement. At low density most Bombus flights were between flowers on a single plant. These geitonogamous pollinations resulted in a lower rate of outcrossing. By contrast, at high density pollinators frequently moved between plants, resulting in a greater proportion of outcrossing.

This result closely parallels findings from two other experimental studies. Krueger \& Knapp (1991) determined outcrossing rates in experimental populations of the bee-pollinated oilseed crop Cuphea lutea. Multi- locus estimates of outcrossing were 0.17 to 0.26 in lowdensity populations and 0.36 to 0.54 in high-density populations. Outcrossing rates were also positively correlated with population density in Bombuspollinated Salvia pratensis (Van Treuren et al., 1993). Multilocus estimates of outcrossing were 0.72 to 0.88 in low-density populations and 0.94 to 0.96 in highdensity populations.

In a manipulative experiment with Mimulus guttatus, LeClerc-Potvin \& Ritland (1994) also found that geitonogamous pollination significantly influenced selfing rates. These researchers compared mating system estimates for unmanipulated flowers on two sets of plants: 'control' plants, with two unmanipulated flowers, received natural levels of geitonogamous pollination. Unmanipulated flowers on 'treated' plants, with one emasculated and one unmanipulated flower, did not receive geitonogamous pollination. Selfing rates were 7.9 per cent higher on 'control' plants because of the effects of geitonogamy.

Individuals of $M$. ringens are usually larger than the annual $M$. guttatus plants studied by LeClerc-Potvin \& Ritland (1994), and frequently have 20 or more open flowers. Since geitonogamy is known to increase with flower number (de Jong et al., 1993), it may have occurred at high frequency in the low-density populations of $M$. ringens.

Although most studies of insect-pollinated species have found a positive relationship between population density and outcrossing rates, negative correlations between density and outcrossing were observed in selfincompatible Helianthus annuus (Ellstrand et al., 1978) and self-incompatible Phlox drummondii (Watkins \& Levin, 1990). In both species, differences among populations resulted from biparental inbreeding, rather than intrafloral or geitonogamous selffertilization. In our study, the type of mating was determined for each sampled seed. Therefore, the observed selfing rate reflects actual self-fertilization; it was not influenced by biparental inbreeding.

Complete paternity exclusion provides more precise estimates of individual outcrossing rates than have been possible with multilocus estimation procedures (Hamrick \& Schnabel, 1985; Brown et al., 1989; Murawski \& Hamrick, 1992; Cruzan et al., 1994). Outcrossing rates of pollen-fertile individuals varied considerably within populations, ranging from 0.10 to 0.55 in one of the high-density populations. Recent studies have demonstrated significant among-family variation in autofertility in Mimulus guttatus (Carr \& Fenster, 1994; Robertson et al., 1994). It would be interesting to determine whether heritable variation for individual outcrossing rates exists in natural plant populations. 


\section{Acknowledgements}

We are grateful to James Reinartz and Lou Nelson for designing and building experimental research gardens at the UW-Milwaukee Field Station. We thank Thomas Schuck for advice and assistance propagating $M$. ringens. Norman Ellstrand, Diane Marshall, James Reinartz, William Schuster, Donald Waller, Joyce Witebsky and two anonymous reviewers provided helpful comments on the manuscript. This research was supported by United States National Science Foundation grant DEB-9119311 to JDK and by a research award from the Graduate School of UWMilwaukee. This is publication number 147 of the UW-Milwaukee Field Station.

\section{References}

AlDE, T. M. 1986. The influence of wind and animal pollination on variation in outcrossing rates. Evolution, 40, 434-435.

BARRETT, S. C. H. AND ECKERT, C. G. 1990. Variation and evolution of mating systems in seed plants. In: Kawano, S. (ed.) Biological Approaches and Evolutionary Trends in Plants, pp. 229-254. Academic Press, London.

BARRETT, S. C. H. AND HUSBAND, B. C. 1990. Variation in outcrossing rates in Eichhornia paniculata: the role of demographic and reproductive factors. $\mathrm{Pl}$. Sp. Biol., 5, 41-56.

BATEMAN, A. J. 1956. Cryptic self-incompatibility in the wallflower: Cheiranthus cheiri L. Heredity, 10, 257-261.

BROWN, A. H. D., BURDON, J. J. AND JAROSZ, A. M. 1989. Isozyme analysis of plant mating systems. In: Soltis, D. E. and Soltis, P. S. (eds) Isozymes in Plant Biology, pp. 73-86. Dioscorides Press, Portland, OR.

CAMPBELL, J. M. AND ABBOTT, R. J. 1976. Variability in outcrossing frequency in Senecio vulgaris L. Heredity, 36, 267-274.

CARR, D. E. AND FENSTER, C. B. 1994. Levels of genetic variation and covariation for Mimulus (Scrophulariaceae) floral traits. Heredity, 72, 606-618.

CLEGG, M. T. AND EPPERSON, B. K. 1988. Natural selection of flower color polymorphisms in morning glory populations. In: Gottlieb, L. D. and Jain, S. K. (eds) Plant Evolutionary Biology, pp. 255-273. Chapman and Hall, London.

CRUZAN, M. B., HAMRICK, J. L., ARNOLD, M. L. AND BENNETT, B. D. 1994. Mating system variation in hybridizing irises: effects of phenology and floral densities on family outcrossing rates. Heredity, 72, 95-105.

DARWIN, C. 1876. Effects of Cross- and Self-fertilization in the Vegetable Kingdom. Murray, London.

DE JONG, T. J., WASER, N. M. AND KLINKHAMER, P. G. L. 1993. Geitonogamy: the neglected side of selfing. Trends Ecol. Evol., 8, 321-325.

DoLE, J. A. 1990 . Role of corolla abscission in delayed selfpollination of Mimulus guttatus (Scrophulariaceae). Am. J. Bot., 77, 1505-1507.
DOLE, J. A. 1991. Evolution of Mating Systems in the Mimulus guttatus Complex. Ph. D. Dissertation, University of California, Davis.

DOLE, J. A. 1992. Reproductive assurance mechanisms in three taxa of the Mimulus guttatus complex (Scrophulariaceae). Am. J. Bot., 79, 650-659.

ELLSTRAND, N. C. 1984. Multiple paternity within the fruits of the wild radish, Raphanus sativus. Am. Nat., 123, 819-828.

ELlSTRAND, N. C., TORRES, A. M. AND LEvin, D. A. 1978. Density and the rate of apparent outcrossing in Helianthus annuus (Asteraceae). Syst. Bot., 3, 403-407.

EPPERSON, B. K. AND CLEGG, M. T. 1987. Frequency-dependent variation for outcrossing rate among flower-color morphs of Ipomoea purpurea. Evolution, 41, 1302-1311.

GODT, M. J. W. AND HAMR1CK, J. L. 1991. Estimates of outcrossing rates in Lathyrus latifolius populations. Genome, 34, 988-992.

Grant, A. L. 1924. A monograph of the genus Mimulus. Ann. Mo. Bot. Gard., 11, 99-388.

HAMRICK, J. L. AND SCHNABEL, A. 1985. Understanding the genetic structure of plant populations: some old problems and a new approach. In: Gregorius, H.-R. (ed.) Lecture Notes in Biomathematics, vol. 60, Population Genetics in Forestry, pp. 50-70. Springer-Verlag, Berlin.

HANDEL, S. N. 1983. Contrasting gene flow patterns and genetic subdivision in adjacent populations of Cucumis sativus (Cucurbitaceae). Evolution, 37, 760-771.

HARDING, J. AND BARNES, K. 1977. Genetics of Lupinus. X. Genetic variability, heterozygosity, and outcrossing in colonial populations of Lupinus succulentus. Evolution, 31, 247-255.

HOLTSFORD, T. P. AND ELLSTRAND, N. C. 1989. Variation in outcrossing rate and population genetic structure of Clarkia tembloriensis (Onagraceae). Theor. Appl. Genet., 78, 480-488.

HOLTSFORD, T. P. AND Ellstrand, N. C. 1992. Genetic and environmental variation in floral traits affecting outcrossing rate in Clarkia tembloriensis (Onagraceae). Evolution, 46, 216-225.

KARRON, J. D. 1995. Genetic consequences of different patterns of distribution and abundance. In: Kunin, W. E. and Gaston, K. J. (eds) The Biology of Rarity. Chapman \& Hall, London, in press.

K1ANG, Y. T. 1972. Pollination study in a natural population of Mimulus guttatus. Evolution, 26, 308-310.

KOHN, J. R. AND BARRETT, S. C. H. 1992. Experimental studies on the functional significance of heterostyly. Evolution, 46, 43-55.

KRUEGER, S. K. AND KNAPP, S. J. 1991. Mating systems of Cuphea laminuligera and Cuphea lutea. Theor. Appl. Genet., 82, 221-226.

KUNIN, w. E. 1992. Density and reproductive success in wild populations of Diplotaxis erucoides (Brassicaceae). Oecologia, 91, 129-133.

KUNIN, w. E. 1993. Sex and the single mustard: population density and pollinator behavior effects on seed-set. Ecology, 74, 2145-2160. 
LECLERC-POTVIN, C. AND RITLAND, K. 1994. Modes of self-fertilization in Mimulus guttatus (Scrophulariaceae): a field experiment. Am. J. Bot., 81, 199-205.

LLOYD, D. G. AND SCHOEN, D. J. 1992. Self- and cross-fertilization in plants. I. Functional dimensions. Int. J. Plant Sci., 153, 358-369.

MARSHALL, D. F. AND ABBOTT, R. J. 1984. Polymorphism for outcrossing frequency at the ray floret locus in Senecio vulgaris L. III. Causes. Heredity, 53, 145-149.

MORGAN, M. T. AND BARRETT, S. C. H. 1990 . Outcrossing rates and correlated mating within a population of Eichhornia paniculata (Pontederiaceae). Heredity, 64, 271-280.

MOTTEN, A. F. AND ANTONOVICS, J. 1992. Determinants of outcrossing rate in a predominantly self-fertilizing weed, Datura stramonium (Solanaceae). Am. J. Bot., 79, 419-427.

MURAWSKI, D. A. AND HAMRICK, J. L. 1991. The effect of the density of flowering individuals on the mating system of nine tropical tree species. Heredity, 67, 167-174.

MURAWSKI, D. A. AND HAMRICK, J. L. 1992. Mating system and phenology of Ceiba pentandra (Bombacaceae) in Central Panama. J. Hered., 83, 401-404.

RIDGEWAY, G. J., SHERBURNe, S. W. AND LeWIS, R. D. 1970. Polymorphisms in the esterases of Atlantic herring. Trans. Am. Fish. Soc., 99, 147-151.

RITLAND, C. AND RITLAND, K. 1989. Variation of sex allocation among eight taxa of the Mimulus guttatus species complex. Am. J. Bot, 76, 1731-1739.

RITLAND, K. 1989. Genetic differentiation, diversity, and inbreeding in the mountain monkeyflower (Mimulus caespitosus) of the Washington Cascades. Can. J. Bot, 67, 2017-2024.

RITLAND, K. AND GANDERS, F. R. 1987a. Covariation of selfing rates with parental gene fixation within populations of Mimulus guttatus. Evolution, 41, 760-771.

RITLAND, K. AND GANDERS, F. R. 1987b. Crossability of Mimulus guttatus in relation to components of gene fixation. Evolution, 41, 772-786.

ROBERTSON, A. W., DIAZ, A. AND MACNAIR, M. R. 1994. The quantitative genetics of floral characters in Mimulus guttatus. Heredity, 72, 300-311.

SAS INSTITUTE. 1990. SAS/STAT User's Guide, version 6, 4th edn. SAS Institute Inc., Cary, NC.
SCHEMSKE, D. W. AND LANDE, R. 1985. The evolution of selffertilization and inbreeding depression in plants. II. Empirical observations. Evolution, 39, 41-52.

SCHOEN, D. J. 1982. The breeding system of Gilia achilleifolia: variation in floral characteristics and outcrossing rate. Evolution, 36, 352-360.

STEel, R. G. D. AND TORRIE, J. H. 1980. Principles and Procedures of Statistics: a Biometrical Approach, 2nd edn. McGrawHill, New York.

STUBER, C. W., GOODMAN, M. M. AND JOHNSON, F. M. 1977. Genetic control and racial variation of $\beta$-glucosidase isozymes in maize (Zea mays L. ). Biochem. Genet., 15, 383-394.

SUTHERLAND, S. AND VICKERY, R. K., Jr. 1988. Trade-offs between sexual and asexual reproduction in the genus Mimulus. Oecologia, 76, 330-335.

VALDEYRON, G., DOMMÉE, B. AND VERNET, Ph. 1977. Self-fertilization in male-fertile plants of a gynodioecious species: Thymus vulgaris L. Heredity, 39, 243-249.

VAN TREUREN, R., BIJLSMA, R., OUBORG, N. J. AND VAN DELDEN, W. 1993. The effects of population size and plant density on outcrossing rates in locally endangered Salvia pratensis. Evolution, 47, 1094-1104.

WALLER, D. M. 1986. Is there disruptive selection for selffertilization? Am. Nat., 128, 421-426.

WALLER, D. M. AND KNIGHT, S. E. 1989. Genetic consequences of outcrossing in the cleistogamous annual, Impatiens capensis. II. Outcrossing rates and genotypic correlations. Evolution, 43, 860-869.

WATKINS, L. AND LEVIN, D. A. 1990. Outcrossing rates as related to plant density in Phlox drummondii. Heredity, 65, 81-90.

WENDEL, J. F. AND WEEDEN, N. F. 1989. Visualization and interpretation of plant isozymes. In: Soltis, D. E. and Soltis, P. S. (eds) Isozymes in Plant Biology, pp. 5-45. Dioscorides Press, Portland, OR.

WILLIS, J. H. 1993. Effects of different levels of inbreeding on fitness components in Mimulus guttatus. Evolution, 47, 864-876.

WYATT, R. 1984a. The evolution of self-pollination in granite outcrop species of Arenaria. I. Morphological correlates. Evolution, 38, 804-816.

WYATT, R. 1984b. The evolution of self-pollination in granite outcrop species of Arenaria. IV. Correlated changes in the gynoecium. Am. J. Bot., 71, 1006-1114. 